\title{
Pengaruh Waktu Pemeraman Pada Stabilisasi Tanah Lempung dengan Campuran Limbah Batu Gamping di Tinjau dari Kuat Geser Tanah
}

\author{
Oktovianus Kambu', Gati Sri Utami ${ }^{2}$ \\ ${ }^{1}$ Teknik sipil, Fakultas Teknik Sipil dan Perencanaan, Institut Teknologi Adhi Tama Surabaya \\ ${ }^{2}$ Teknik sipil, Fakultas Teknik Sipil dan Perencanaan, Institut Teknologi Adhi Tama Surabaya \\ Email: 1fita.fina3@gmail.com
}

\begin{abstract}
Subgrade type marine soft clay formed from weathering marine biota sedimentation. If the subgrade has low bearing capacity and high swelling, then buildings on the ground often suffer damage such as soil in the East Wonorejo area. So that before the land is used as a subgrade, it is first repaired. One of the methods used to repair is stabilization with a mixture of limestone waste. The percentage of mixture is $6 \%$, 9\%, 12\% with allowing 6, 12, 18 days. Laboratory testing includes: Sieve Analysis, Atterberg Limit, Proctor standard, and Direct Shear. The test results of the East Wonorejo clay before stabilization with a mixture of limestone waste is the Plasticity Index (PI) value $=40.55 \%$ with a cohesion value $(C)=0.1394 \mathrm{~kg} / \mathrm{cm}^{2}$ and the deep shear angle $(\varphi)=23.96^{\circ}$. Addition of limestone waste and allowing times to clay soil stabilization can dicreasing the plasticity and increasing shear strength parameters. The smallest plasticity index value in the mixture $12 \%$ allowing time 18 days $(P I=16.37 \%)$ the largest cohesion value in the mixture $12 \%$ allowing 12 days $\left(C=0.3467 \mathrm{Kg} / \mathrm{cm}^{2}\right)$ and the deep shear angle in $12 \%$ allowing 18 days $(\varnothing$ $\left.=81.73^{\circ}\right)$. The optimum percentage of limestone waste as a clay stabilization mixture is $12 \%$ limestone with allowing 12-day blacking both to dicrease the plasticity and increase the value of the soil shear strength parameters.
\end{abstract}

Keywords: Atterberg Limit, Direct shear, limestone waste, Standatr Proctor, Stabilitation

\begin{abstract}
Abstrak
Tanah dasar berjenis marine soft clay yang terbentuk dari sedimentasi pelapukan biota laut. Jika tanah dasar tersebut mempunyai daya dukung rendah dan kembang susut yang tinggi, maka bangunan yang ada diatas tanah tersebut sering mengalami kerusakan seperti tanah di daerah Wonorejo Timur. Sehingga sebelum tanah tersebut digunakan sebagai tanah dasar, diperbaiki terlebih dahulu. Salah sat metode yang digunakan untuk memperbaiki adalah dengan stabilisasi dengan campuran limbah batu gamping. Prosentase campuran adalah 6\%,9\%,12\% dengan pemeraman 6,12, 18 hari. Pengujian laboratorium meliputi: Analisa Saringan, Atterberg Limit, standart Proctor, dan Direct Shear. Hasil pengujian tanah lempung Wonorejo Timur sebelum distabilisasi dengan campuran limbah batu gamping adalah nilai Indek Plastisitas (IP) $=40,55 \%$ dengan nilai kohesi $(C)=0.1394 \mathrm{Kg} / \mathrm{cm}^{2}$ dan sudut geser dalam $(\varphi)=23,96^{\circ}$. Penambahan prosentase limbah batu gamping dan waktu pemeraman pada stabilisasi tanah lempung dapat menurunkan sifat plastisitas dan menaikan parameter kuat geser. Nilai indek plastisitas terkecil pada campuran $12 \%$ waktu pemeraman 18 hari $(\mathrm{IP}=16.37 \%)$ nilai kohesi terbesar pada campuran $12 \%$ pemeraman 12 hari $(\mathrm{C}=$ $\left.0.3467 \mathrm{Kg} / \mathrm{cm}^{2}\right)$ dan sudut geser dalam pada $12 \%$ pemeraman 18 hari $\left(\varnothing=81.73^{\circ}\right)$. Prosentase limbah batu gamping optimum sebagai campuran stabilisasi tanah lempung adalah batu gamping $12 \%$ dengan pemeraman 12 hari baik untuk menurunkan sifat plastisitas dan menaikan nilai parameter kuat geser tanah.
\end{abstract}

Keywords: Atterberg Limit, Direct shear, limbah batu gamping, Standatr Proctor, Stabilisasi

\section{Latar Belakang}

Daerah Wonorejo Timur merupakan daerah yang berada pada pesisir pantai, pada umumnya lempung yang terdapat daerah pesisir pantai merupakan tanah lempung jenis marine soft clay yang terbentuk dari sedimentasi pelapukan biota laut. Jika suatu kontruksi bangunan terletak di atas tanah dasar lempung, maka bangunan tersebut perlu diantisipasi karena kadang-kadang sifat tanah lempungnya adalah daya dukung rendah dan plastisitas tinggi. 
Berdasarkan permasalahan diatas, perlu adanya upaya kuat geser tanah untuk dinaikan dan menurunkan plastisitas pada tanah daerah wonorejo timur. Salah satu cara yang digunakan adalah metode stabilisasi kimiawi dan mekanis. Stabilisasi secara kimiawi adalah stabilisasi dengan ditambahkan suatu zat lain kedalam tanah sehingga terjadi perubahan sifat fisik tanah. Pada penelitian ini dilakukan stabilisasi tanah lempung dengan campuran limbah batu gamping yang mengandung kalsium karbonat $\left(\mathrm{CaCO}_{3}\right)$, bersifat keras dan tidak larut dalam air dengan harapan dapat memperbaiki struktur dan sifat fisik tanah. Limbah batu gamping yang berasal dari bukit kidul jadih Madura, karena pada limbah batu gamping belum diketahui prosentase kimia maka dilakukan uji kimiawi lanjutan, di laboratorium Robotika ITS Surabaya.

Penelitian ini dilakukan dengan skala laboratorium dengan berbagai prosentase campuran limbah batu gamping dan waktu pemeraman. Pada penelitian ini diharapkan stabilisasi dengan limbah batu gamping dapat meningkatkan meningkatkan kuat geser dan menurunkan plastisitas tanah.

\section{Studi Literatur}

\subsection{Stabilisasi Tanah}

Dalam merencanakan suatu konstruksi yang terletak di atas tanah dasar yang kondisinya jelek, maka harus dipertimbangkan hal-hal berikut ini :

1. Menerima kondisi tanah apa adanya, dan merencana konstruksi yang sesuai dengan kondisi tanah yang ada.

2. Lapisan tanah yang jelek dibuang dan diganti dengan tanah yang lebih baik.

3. Perilaku tanah asli diperbaiki sehingga tanah asli berubah dan dapat memenuhi persyaratan yang diinginkan, yang dikenal sebagai "Metoda Stabilisasi".

Tanah merupakan salah satu bahan yang langsung tersedia di lapangan, dan apabila langsung dapat dipergunakan akan sangat ekonomis. Suatu tanah yang terdapat di lapangan bersifat sangat lepas atau sangat mudah tertekan, atau bila mempunyai indeks konsistensi yang tidak sesuai, mempunyai permeabilitas yang terlalu tinggi atau mempunyai sifat lain yang tidak diinginkan sehingga tidak sesuai untuk suatu proyek pembangunan, maka tanah tersebut harus dilakukan stabilisasi. Stabilisasi dapat terdiri dari salah satu tindakan sebagai berikut:

1. Menambah kerapatan tanah.

2. Menambah material yang tidak aktif sehingga mempertinggi kohesi dan atau tahanan geser yang timbul.

3. Menambah material untuk menyebabkan perubahan-perubahan kimiawi dan fisik dari material tanah.

4. Merendahkan muka air (drainase tanah).

5. Mengganti tanah-tanah yang buruk.

Stabilisasi tanah terdiri dari salah satu atau gabungan pekerjaan-pekerjaan berikut:

1. Stabilisasi dengan berbagai macam peralatan mekanis seperti:

a. Mesin gilas (roller).

b. Benda-benda berat yang dijatuhkan (pounder).

c. Pemadatan dengan alat peledak (eksplosive).

d. Tekanan statis.

e. Pembekuan.

f. Pemanasan dan sebagainya.

2. Bahan pencampur atau tambahan (aditive) seperti :

a. Kerikil untuk kohesif (lempung).

b. Lempung untuk berbutir kasar.

c. Percampuran kimiawi seperti: Semen Portland (PC), Gamping atau kapur, Abu batu bara, asphaIt cement dan sebagainya.

Perbaikan tanah dasar dapat dilakukan antara lain dengan stabilisasi massa tanah, baik secara mekanis maupun secara kimiawi [1]

\subsection{Kuat Geser}


Kuat geser tanah adalah gaya yang berlawanan pada butir-butir tanah terhadap desakan dan tarikan dalam tanah. Dengan dasar pengertian ini, bila tanah mengalami pembebanan akan ditahan oleh: [2]

1. Kohesi tanah (c) dan kepadatan tanah sangat bergantung pada jenis tanahnya, tetapi tidak tergantung pada tegangan normal $(\sigma)$ yang bekerja pada bidang geser

2. Gesekan antara butiran-butiran tanah yang besarnya berbanding lurus dengan tegangan normal pada bidang gesernya.

Rumus tegangan geser:

$$
\tau=\mathrm{c}+\sigma \mathrm{tg}
$$

keterangan:
$\tau=$ tegangan geser tanah
$\mathrm{c}=$ kohesi tanah
$\varphi=$ sudut geser dalam tanah
$\sigma=$ tegangan normal yang pada bidang runtuh

Ada beberapa pengujian tanah di laboratorium untuk menentukan parameter kuat geser tanah, antara lain:

1. Pengujian geser langsung (Direct shear test)

2. Pengujian tiaksial (Triaksial test)

3. Pengujian tekan bebas (Unconfined compression test)

Penelitian ini yang digunakan untuk menentukan kuat geser tanah adalah pengujian geser langsung atau Direct shear test. Pengujian kuat geser ini dilakukan untuk mendapatkan nilai parameter kuat geser yaitu kohesi (c) dan sudut geser dalam ( $\varphi)$.

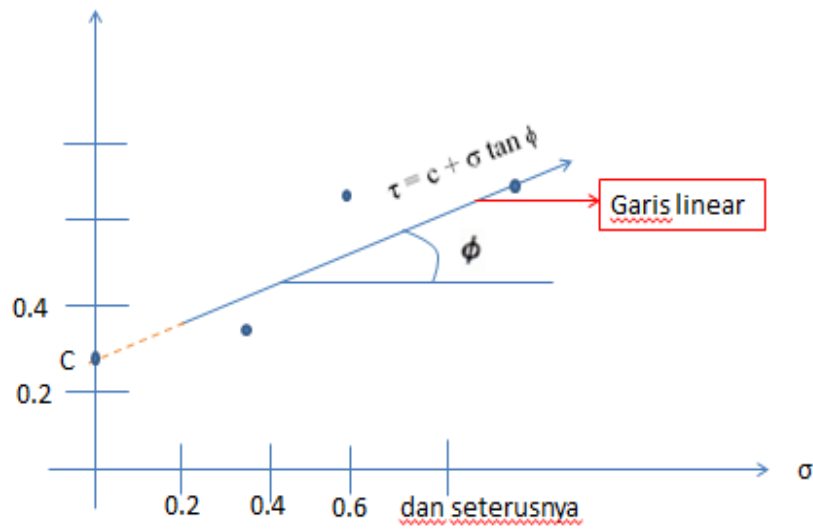

Gambar 1. Hubungan tegangan normal dan tegangan geser

\subsection{Kapur}

Salah satu bahan pengikat partikel adalah kapur dengan karakteristik : sifat plastis baik (tidak getas), mudah dan cepat mengeras, workability baik dan mempunyai daya ikat baik untuk batu dan bata. Bahan dasar kapur adalah batu kapur atau dolomit, yang mengandung senyawa kalsium karbonat Jenis kapur yang banyak digunakan adalah kapur tohor $(\mathrm{CaO})$ dan kapur padam atau Hydrated lime $\left[\mathrm{Ca}(\mathrm{OH})^{2}\right]$. Metode Stabilitasi Tanah dengan campuran Kapur, sampel tanah dari Sendang Mulyo dan kapur dari Purwodadi, Tanah asli + kapur dengan persentase kapur 0\%, 5\%, 8\%, 10\%, 12\%. CBR unsoacked: persentase $10 \%$, dari $11,8 \%$ menjadi $22,1 \%$, tetapi pada persentase kapur $12 \%$ CBR turun sedikit menjadi $22,0 \%$. CBR soacked: persentase $10 \%$, dari $2,45 \%$ menjadi 7,6 \%, tetapi pada persentase kapur $12 \%$ CBR turun sedikit menjadi 7,58 \%. Swelling mengalami penurunan dengan bertambahnya persentase kapur dengan kata lain semakin banyak prosentase kapur semakin kecil swelling yang terjadi [3]

Kapur sebagai bahan stabilisasi tanah lempung dapat meningkatkan kepadatan, kuat geser tanah berdasarkan nilai tegangan geser dan kohesi. Pada awalnya tanah lempung termasuk tanah yang sangat lunak (C : $0,116 \mathrm{~kg} / \mathrm{cm} 2)$ setelah ditambah kapur menjadi cukup keras $(\mathrm{C}: 0,373 \mathrm{~kg} / \mathrm{cm} 2)$. Prosentase optimum penambahan kapur supaya menjadikan tanah lempung dalam katagori cukup keras pada prosentase10\%. [4]

Clay Soil Stabilisasi With Lime Effek The Value CBR and Swelling. Kapur dapat digunakan sebagai 
bahan campuran stabilisasi tanah lempung untuk menaikan nilai CBR dan menurunkan swelling dengan prosentase optimum 10\%, nilai $\mathrm{CBR}=16,3 \%, \mathrm{LL}=49,33 \%$, IP $=31,47 \%$ dan swelling $=27,67 \%$.[5]

Stabilisasi Tanah Lempung Dengan Penambahan Kapur, pencampuran kapur dengan tanah menghasikan kekuatan tanah yang lebih tinggi, pengurangan potensi pengembangan dan menambah keawetan. Untuk maksud ini, maka campuran harus dipadatkan dan diberikan waktu untuk terjadinya reaksi kimia yang menghasilkan bahan campuran dengan sementasi tinggi. [6]

Kapur Tohor berasal dari pembakaran batu kapur/batu gamping (lime stone), disamping itu dikenal pula kapur padam yang merupakan hasil pemadaman kapur tohor dengan air, dengan reaksi kimia:

$$
\mathrm{CaO}+\mathrm{H}_{2} \mathrm{O} \quad \boldsymbol{\mathrm { V }} \quad \mathrm{Ca}(\mathrm{OH})
$$

Kapur merupakan bahan baku campuran adukan kapur, yang banyak digunakan, dalam pelaksanaan pembangunan. Kapur yang dikenal di Indonesia umumnya kapur udara (kapur yang mengeras dengan $\mathrm{CO}_{2}$ dari udara). Kapur diperoleh dari pembakaran batu kapur, kulit kerang, atau karang laut. Reaksi kimia yang terjadi pada pembakaran kapur sebagai berikut:

Reaksi:

Keterangan:

$$
\mathrm{CaCO} 3 \rightleftharpoons \mathrm{CaO}+\mathrm{CO}_{2}
$$

$$
\begin{array}{ll}
\mathrm{CaCO}_{3} & =\text { Batu kapur } \\
\mathrm{CaO} & =\text { Kapur tohor } \\
\mathrm{CO}_{2} & =\text { Karbon dioksida }
\end{array}
$$

\subsection{Tanah Lempung}

Mineral lempung (clay mineral) yang merupakan produk pelapukan kimia dari fedspar, feromagnesium dan berjenis-jenis mika adalah yang membentuk sifat plastis tanah. Ada tiga tipe utama mineral lempung yaitu : Kaolinite, illite dan montmorillonite

Lempung mempunyai beberapa sifat yang membedakannya dengan tanah lain yaitu ukuran butir halus (kurang dari 0,002 $\mathrm{mm}$ ), permeabilitas rendah, kenaikan air kapiler tinggi, bersifat sangat kohesif, serta proses konsolidasinya bersifat lambat.

Plastisitas merupakan karakteristik yang penting dalam hal tanah berbutir halus. Istilah plastisitas adalah kemampuan tanah untuk berdeformasi pada volume tetap tanpa terjadi retakan atau remahan. Plastisitas terdapat pada tanah yang memiliki mineral lempung atau bahan organic.

Dalam lempung terdapat kaolinite dan khlorit yang bisa juga mengandung silika dan brusit $\left(\mathrm{Mg}(\mathrm{OH})_{2}\right)$. Sedangkan dalam jenis lain lempung koloida (koloid dengan air) tidak hanya terdiri dari silika (Si), aluminium $(\mathrm{Al})$ \& oksigen $(\mathrm{O})$ tapi juga kalsium $(\mathrm{Ca})$, magnesium $(\mathrm{Mg})$, kalium $(\mathrm{K})$, fosfor $(\mathrm{F})$, nitrogen $(\mathrm{N})$ dan lain sebagainya.

Struktur butir kaolinite terdiri atas satu lapisan silika tetrahedran dan satu lapisan alumina oktahedron. Antara lapisan-lapisan ini terdapat ikatan agak kuat disebabkan oleh hidrogen. Butir illite terdiri atas satu lapisan alumina antara dua lapisan silika. Kesatuan baru ini diikat satu sama lain dengan ikatan potassium. Ikatan semacam ini kurang kuat. Struktur montmorillonite tidak jauh berbeda dengan struktur illite, tetapi ikatan antar lapisan berbeda, yaitu terdiri atas air serta "exchangeable cations".

Kadang-kadang tanah lempung mempunyai sifat-sifat yang tidak menguntungkan, seperti CBR rendah, kembang susut tinggi sehingga apabila dipergunakan untuk tanah dasar akan menghasilkan suatu konstruksi yang umurnya tidak sesuai rencana atau cepat rusak. Sebaiknya sebelum dipergunakan sebagai tanah dasar suatu konstruksi, nilai CBR dinaikkan supaya mampu menahan beban di atasnya, kembang susut (swelling) diturunkan agar volume tanah stabil bila kena air tidak mengembang sebaliknya tidak mudah meyusut sehingga retak-retak.

\section{Metode Penelitian}

Alur penelitian yang dilakukan seperti yang ditampilkan Gambar 2. 


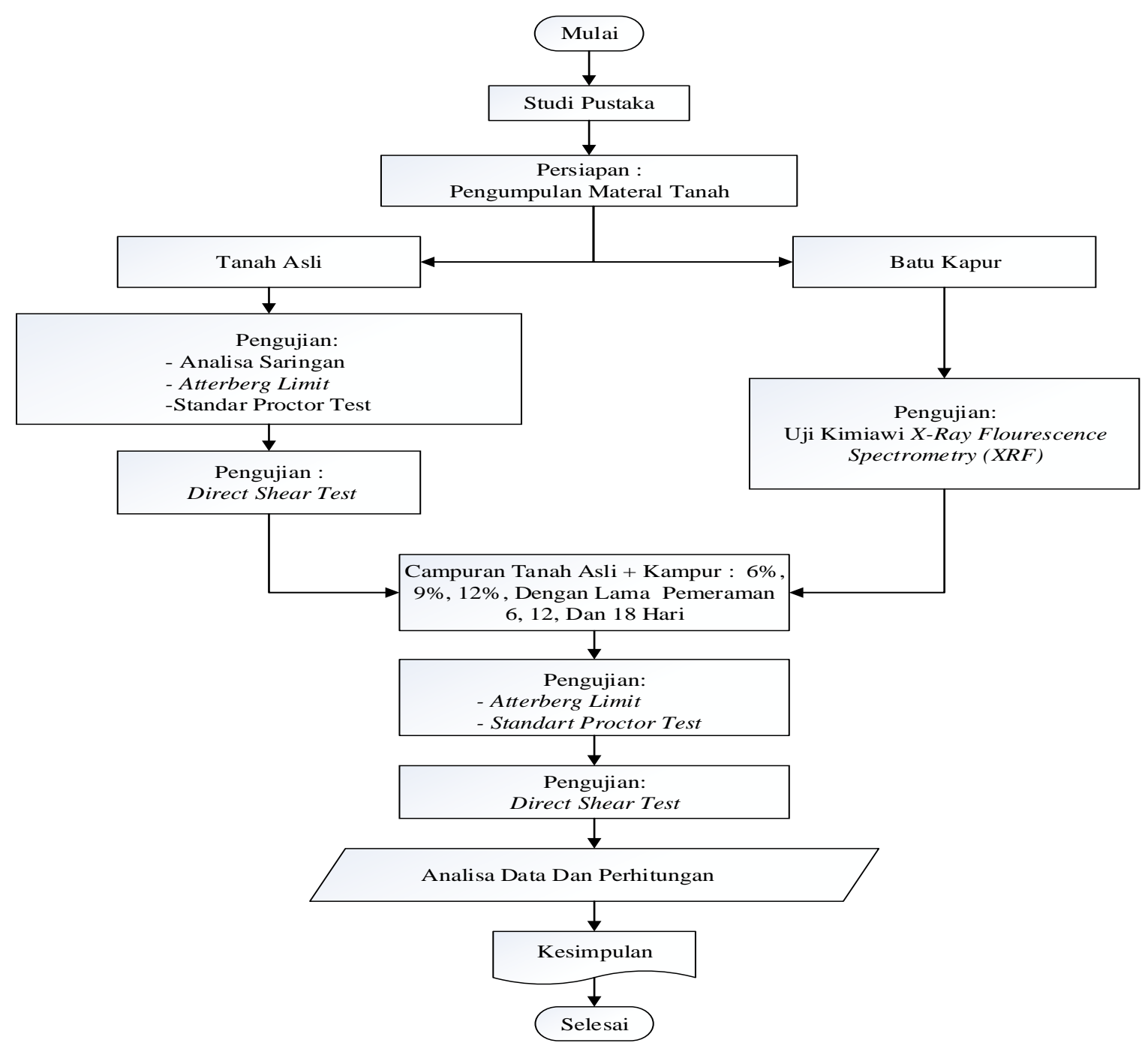

Gambar 2. Diagram Penelitian

Sampel tanah lempung lunak diambil dari daerah perumahan Wisata Semanggi Mangrove Wonorejo.

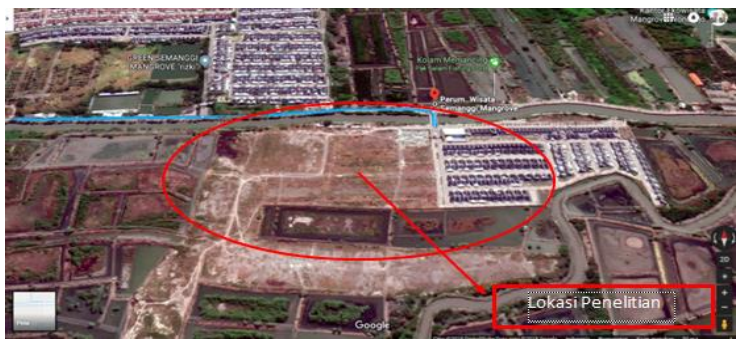

Gambar 3. Lokasi Pengambilan Sample Tanah

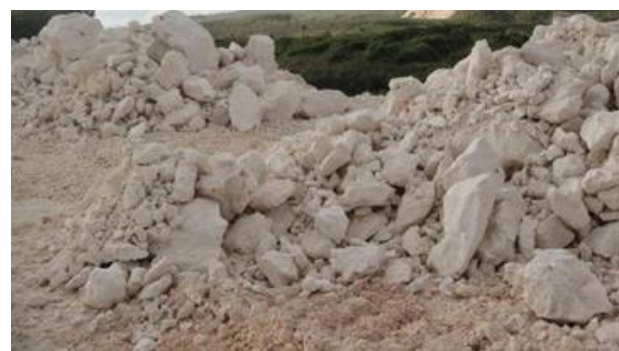

Gambar 4. Batu kapur Untuk Pengujian

\section{Hasil dan Pembahasan}

\subsection{Pengujian Batu kapur}


Tabel 1. Hasil Pengujian Serbuk Limbah Batu Gamping

\begin{tabular}{|c|c|c|c|}
\hline No & Compound & Conc & Unit \\
\hline 1 & $\mathrm{CaO}$ & 99,52 & $0 \%$ \\
\hline 2 & $\mathrm{Fe}_{2} \mathrm{O}_{3}$ & 0,067 & $0 \%$ \\
\hline 3 & $\mathrm{CuO}$ & 0,07 & $0 \%$ \\
\hline
\end{tabular}

Dari Tabel 1. dapat dilihat kadar $\mathrm{CaO}+\mathrm{Fe}_{2} \mathrm{O}_{3}+\mathrm{CuO}>70 \%$ (ASTM C618-92a), maka limbah batu gamping tergolong pozzoland kelas $\mathrm{C}$ dimana kandungan kalsium oksida $(\mathrm{CaO})$ lebih dari $10 \%$ yang dihasilkan dari pembakaran.

\subsection{Pengujian Tanah Asli}

\section{Uji Analisis gradasi}

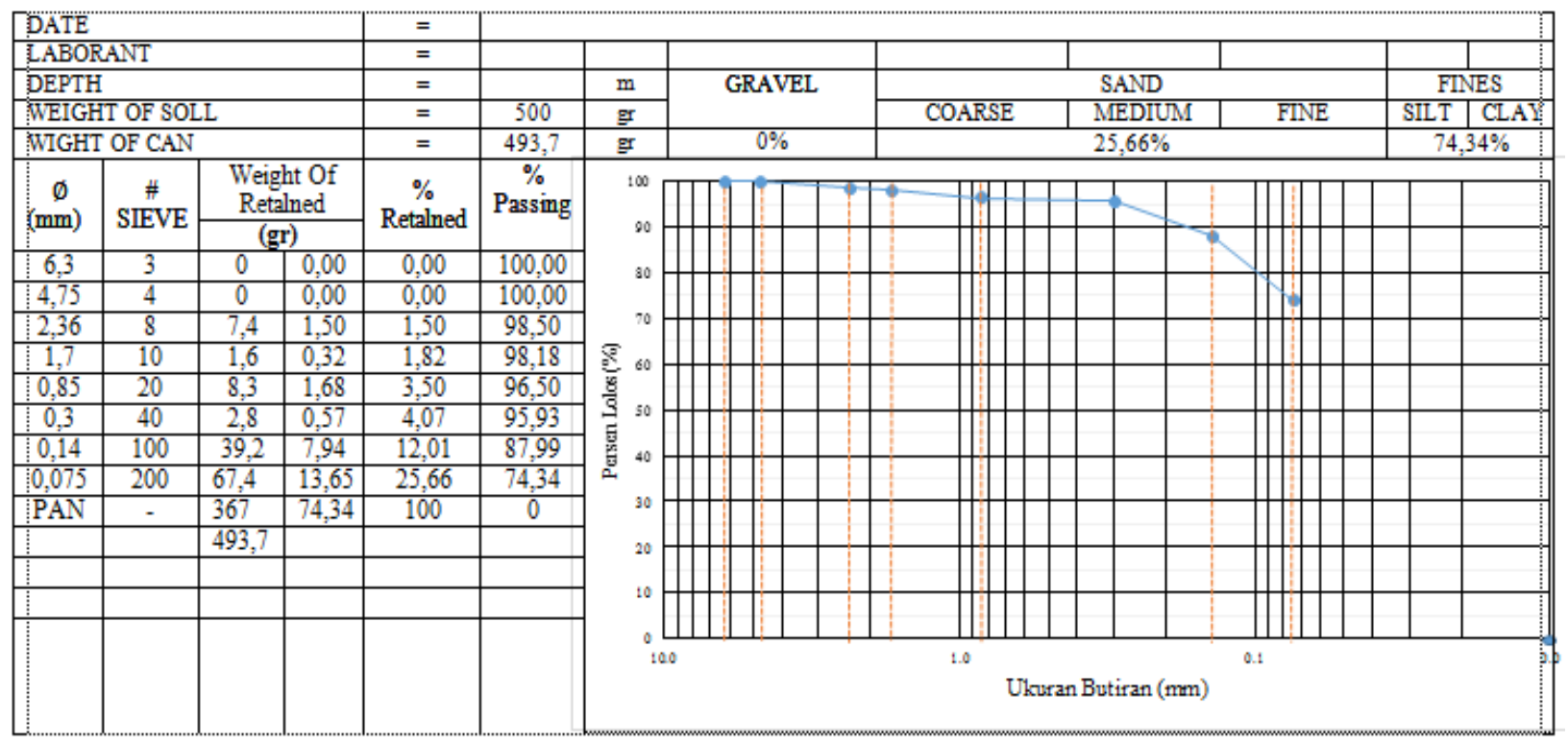

Gambar 5. hasil analisis data pengujian gradasai butiran tanah asli

Berdasarkan gambar 5, prosentase lolos 0,075mm sebesar 74,34\% > 50\%, Maka dikategorikan tanah berbutir halus.

\section{Uji Atterberg Limit}

Tabel 2.Hasil Uji Indeks Plastisitas

\begin{tabular}{|l|c|c|}
\hline \multicolumn{1}{|c|}{ Name Item } & Rumus & Kadar Air \\
\hline LL (\%) & LL & 60,86 \\
\hline PL (\%) & PL & 20,31 \\
\hline IP( \%) & IP = LL - PL & 40,55 \\
\hline
\end{tabular}

Dilihat dari Gambar 6 berdasarkan nilai Liquid Limit pada tanah asli senilai 60,86\% dengan plasticity Index (PI) senilai 40,55\%, tanah tersebut termasuk tanah lempung plastisitas tinggi. 


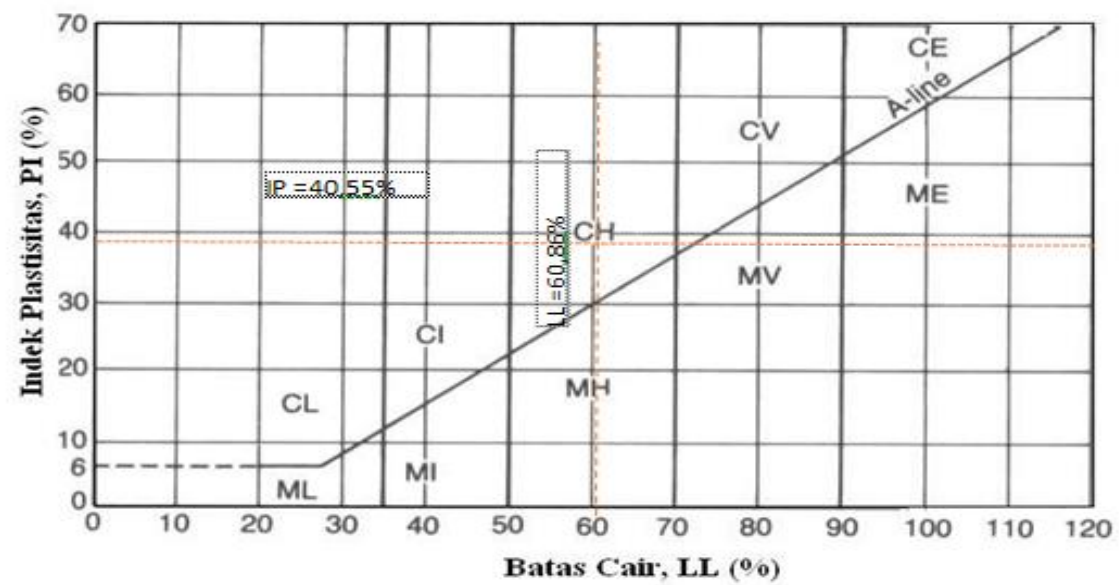

Gambar 6. Hubungan Nilai Liquid Limit (LL) dan Plasticity Index (PI)

\subsection{Pengujian Tanah Campuran}

\section{Atterberg Limit}

Tabel 3. Nilai Indeks Plastisitas

\begin{tabular}{|c|c|c|c|c|}
\hline \multirow{2}{*}{$\begin{array}{c}\text { Prosentase } \\
\text { Campuran }(\%)\end{array}$} & \multicolumn{4}{|c|}{ Waktu Pemeraman (Hari) } \\
\cline { 2 - 5 } & 0 & 6 & 12 & 18 \\
\hline $6 \%$ & 40.55 & 28.92 & 25.51 & 25.39 \\
\hline $9 \%$ & 40.55 & 28.07 & 24.29 & 16.52 \\
\hline $12 \%$ & 40.55 & 16.73 & 16.48 & 16.37 \\
\hline
\end{tabular}

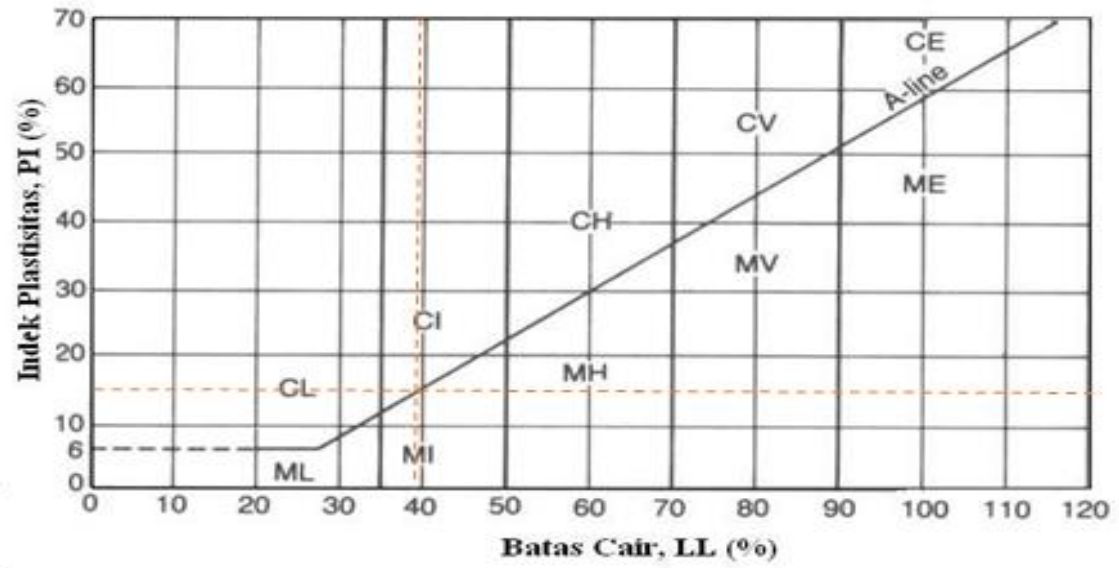

Gambar 7. Hubungan Nilai Liquid Limit (LL) dan Plasticity Index (PI) 12\% waktu pemeraman 18 hari

Dilihat dari gambar berdasarkan nilai liquid limit tanah campuran 39,40\%. dengan Plasticity Index 16,37\%., maka tanah tersebut termaksud tanah lempung berplastisitas rendah. Berdasarkan Gambar 8 hubungan antara prosentase campuran limbah batu kapur gamping dengan nilai indeks plastis dapat diketahui:

- semakin besar prosentase limbah batu kapur gamping sebagai bahan campuran stabilisasi, maka semakin turun nilai indeks plastis.

- semakin lama waktu pemeraman limbah batu kapur gamping + tanah lempung, maka semakin turun nilai indeks plastisitasnya. 


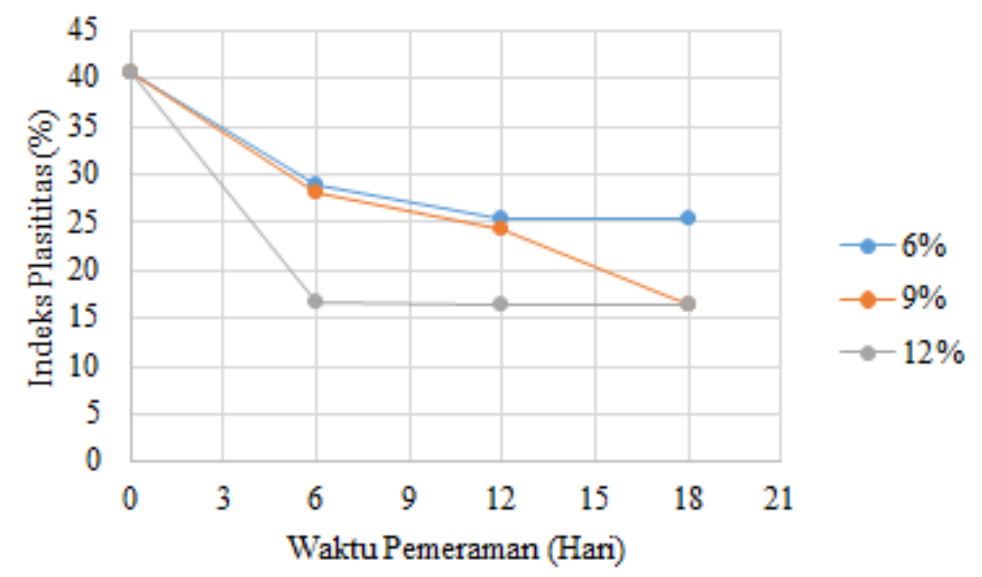

Gambar 8. Hubungan antara waktu pemeraman dan Indek Plastisitas untuk berbagai (\%) campuran

Tabel 4. Penurunan Indeks Plastisitas berdasarkan prosentase campuran

\begin{tabular}{|c|c|c|c|c|}
\hline \multirow{2}{*}{$\begin{array}{c}\text { Waktu } \\
\text { pemerama } \\
\text { n (Hari) }\end{array}$} & \multicolumn{4}{|c|}{ Prosentase campuran (\%) } \\
\cline { 2 - 5 } & 0 & 6 & 9 & 12 \\
\hline 6 & 40.55 & 28,68 & 30,77 & 58,74 \\
\hline 12 & 40.55 & 37,09 & 40,09 & 59,35 \\
\hline 18 & 40.55 & 37,38 & 59,26 & 59,63 \\
\hline
\end{tabular}

Tabel 5. Penurunan Indek Plastisitas berdasarkan waktu pemeraman

\begin{tabular}{|c|c|c|c|c|}
\hline \multirow{2}{*}{ Prosentase Campuran (\%) } & \multicolumn{4}{|c|}{ Waktu Pemeraman (Hari) } \\
\cline { 2 - 5 } & 0 & 6 & 12 & 18 \\
\hline $6 \%$ & 40.55 & 28,68 & 37,09 & 37,38 \\
\hline $9 \%$ & 40.55 & 30,77 & 40,09 & 59,26 \\
\hline $12 \%$ & 40.55 & 58,74 & 59,35 & 59,63 \\
\hline
\end{tabular}

Tabel 6. Nilai Kohesi (C)

\begin{tabular}{|c|c|c|c|}
\hline \multirow{2}{*}{$\begin{array}{c}\text { Prosentase } \\
\text { Campuran (\%) }\end{array}$} & \multicolumn{3}{|c|}{ Kohesi $\left(\mathrm{kg} / \mathrm{cm}^{2}\right) /$ Hari } \\
\cline { 2 - 4 } & 6 & 12 & 18 \\
\hline T. Asli & 0.1394 & 0.1394 & 0.1394 \\
\hline $6 \%$ & 0.1779 & 0.2156 & 0.3051 \\
\hline $9 \%$ & 0.2137 & 0.3087 & 0.3389 \\
\hline $12 \%$ & 0.2668 & 0.3467 & 0.2769 \\
\hline
\end{tabular}

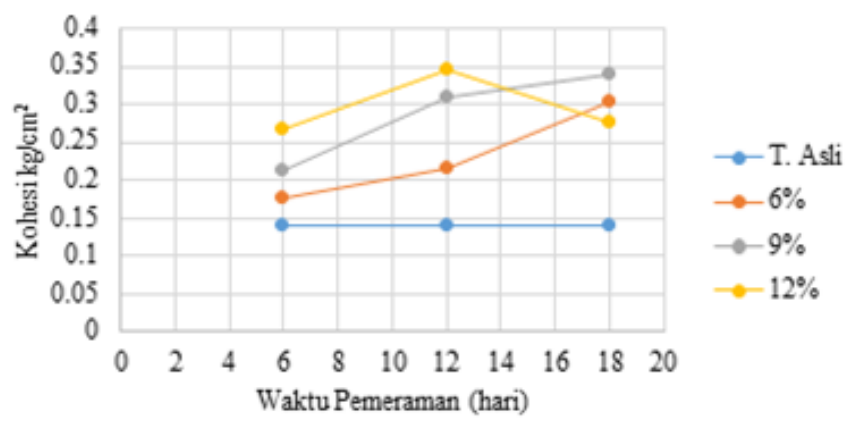

Gambar 9. Hubungan antara waktu pemeraman dan Kohesi untuk berbagai (\%) campuran 
Dari gambar 9 dapat dilihat bahwa semakin lama umur pemeraman, pada umumnya campuran 6\% dan 9\% kohesi semakin meningkat, kecuali $12 \%$ hal ini disebabkan karena kemungkinan ikatan gel silika yang memperkuat ikatan partikel antar tanah sudah terbentuk. Semakin lama waktu pemeraman, ikatan yang terbentuk semakin banyak dan kuat, shingga kohesi meningkat seiring waktu pemeraman.

Tabel 7. Sudut Geser $(\Phi)$ Tanah Asli Dan Campuran Limbah Batu Gamping

\begin{tabular}{|c|c|c|c|}
\hline \multirow{2}{*}{ Prosentase } & \multicolumn{3}{|c|}{ Hari $/ \varphi\left(^{\circ}\right)$} \\
\cline { 2 - 4 } & 6 & 12 & 18 \\
\hline T. Asli & 23.96 & 23.96 & 23.96 \\
\hline $6 \%$ & 65.22 & 68.41 & 74.59 \\
\hline $9 \%$ & 67.28 & 70.78 & 79.62 \\
\hline $12 \%$ & 72.75 & 74.69 & 81.73 \\
\hline
\end{tabular}

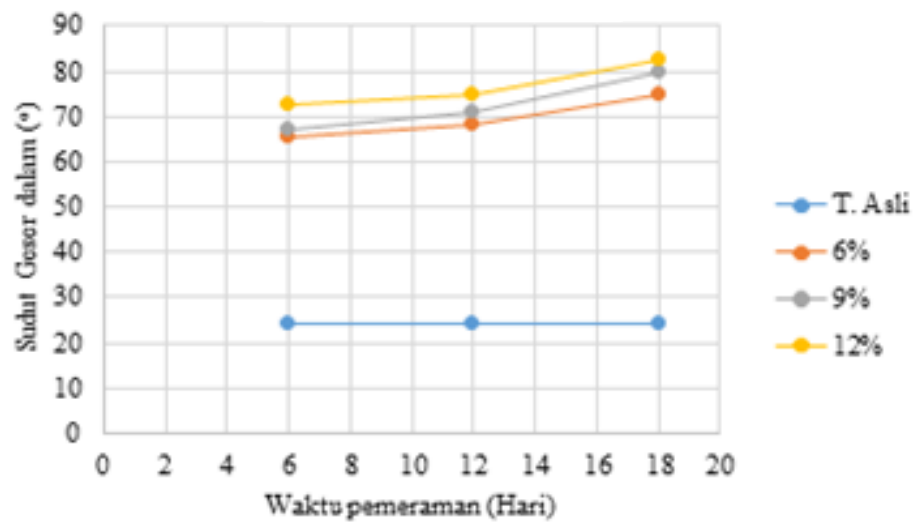

Gambar 10. Hubungan Waktu pemeraman dan Sudut Geser untuk berbagai (\%) campuran

Sudut geser pada gambar 10 pada tiap presentase mengalami peningkatan seiringan semakin lama waktu pemeraman. Hal ini disebabkan karena campuran limbah batu gamping mengisi ruang antara lapisan lempung sehingga tanah menjadi padat serupa dengan pasir padat yang memiliki sudut geser yang besar.

\section{Kesimpulan}

Dari hasil analisa dan pembahasan dapat disimpulkan sebagai berikut:

1. Tanah di daerah Wonorejo Timur sebelum distabilisasi dengan campuran limbah batu gamping adalah nilai Indeks Plastisitas (IP) $=40,55 \%$ dengan nilai kohesi $(C)=0.1394 \mathrm{~kg} / \mathrm{cm}^{2}$ dan sudut geser dalam $(\varphi)$ $=23,96^{\circ}$. Penambahan prosentase limbah batu gamping dan waktu pemeraman pada stabilisasi tanah lempung dapat menurunkan sifat plastisitas dan menaikan parameter kuat geser tanah. Nilai indeks plastisitas terkecil pada campuran $12 \%$ waktu pemeraman 18 hari $(\mathrm{IP}=16.37 \%)$ nilai kohesi terbesar pada campuran $12 \%$ pemeraman 12 hari $\left(\mathrm{C}=0.3467 \mathrm{Kg} / \mathrm{cm}^{2}\right)$ dan sudut geser dalam $12 \%$ pada pemeraman 18 hari $\left(\varnothing=81.73^{\circ}\right)$

2. Prosentase limbah batu gamping optimum sebagai campuran stabilisasi tanah lempung adalah $12 \%$ dengan pemeraman 12 hari baik untuk menurunkan sifat plastisitas dan menaikan nilai parameter kuat geser tanah.

\section{SARAN}

Sebaiknya penelitian ini dilanjutkan dengan prosentase campuran limbah dan waktu pemeraman ditambah dan Pengujian-pengujian yang lain seperti: CBR, Konsolidasi, Oedometer dan Triaxial. 


\section{Referensi}

[1] Hary Christady Hardiyatmo, 2010, Stabilisasi Tanah Untuk Perkerasan Jalan Raya, Yokyakarta: Gadjah Mada University Press.

[2] Bowles J.E, 1984, Physical and Geotechmical Properties of Soils, Second Edition, McGraw-Hill, Singapore

[3] Andrews, oflaherty, warsiti, 2009, Meningkatkan CBR dan Memperkecil Swelling Tanah Sub Grade Dengan Metode Stabilitas Tanah Kapur. (Online), Vol. 14 (1): 38-45

[4] Gati Sri Utami, A. Harris. HA, 2016, Analisis Pemanfaatan Kapur seagai Bahan Stabilisasi Tanah Lempung Ditinjau dari Kuat Geser, Prosiding SNTEKPAN VI, A1- 7

[5] Gati Sri Utami, 2014, Clay Soil Stabilisasi With Lime Effek The Value CBR and Swelling, ARPN vol. 9 no.10, Pakistan.

[6] Fitra, Rony. Shervi, 2009.Stabilisasi Tanah Lempung Dengan Penambahan Pasir dan Kapur. (Online), Fakultas Teknik Universitas Andalas. (http://repository.unand.ac.id/13461/, diakses 8 Maret 2013, 11:31 AM) 